\title{
Turkey and Violence in the Countryside
}

\author{
Sinan Çaya* \\ Boğaziçi University, Turkey
}

Submission: January 10, 2017; Published: February 09, 2017

*Corresponding author: Sinan Çaya, Boğaziçi University, Institute of Environmental Sciences, Istanbul, Turkey, Email: sinan.caya@gmail.com

\begin{abstract}
The violence encountered on the countryside in Turkey is different from its counterpart in metropolitan areas by nature and this is only expected. Matters of honor regarding chastity, dispute over land, personal conflict and enmity leading to a crime or fights among children drifting along adults or trouble befalling close kin or friends and quickly encompassing those feeling responsible for them are the most frequently encountered forms of infringing the penal law. Some cultural traits also pave the way to possible violence easily. Personal memories are made use of in the article.

Keywords: Violence; Crime; Rural area; Young; Cultural grounds
\end{abstract}

\section{Introduction}

In rural Turkey it is mostly young people who indulge in violence and crime since young individuals are hot tempered, inexperienced and uncalculative in their dealings with other young people. Shaw [1] asserts that Turkey is an agricultural country where people mostly live in villages under simple conditions. The inmates in prisons reflect this fact. The convict is usually a villager between the ages of 22-39 and the crime committed is due to revenge, jealousy or land dispute, he relates. Indeed, on the countryside even crimes are of rural nature. Armed robbery, a peculiarity of urban centers is never encountered for instance. Instead offences in accordance with rural life do occur from time to time. Some cultural grounds and reasons appear to back up certain possibilities of violence. On Black Sea, Eastern and Southeastern Anatolia regions village boys are taught how to handle guns. Turks, as a war-waging nation, do possess a long tradition of arms. As the expression goes "my horse, my woman and my weapon are my most precious items". Our people used to keep arms against bandits. Arms symbolize courage as in the saying "the sign of a landlord is his generosity; the sign of a brave man is his marksmanship" (Figure 1).

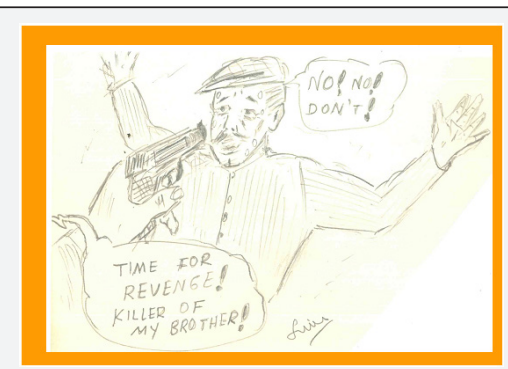

Figure 1: In the feudal environmentent kinship is important and thus a common ground for the act of murder is revenging a close kin (illustration by the author).
Arms are provided by smugglers, who even access remote villages. Children who grow up with weapons resort to using them in the smallest quarrels [2]. Tezcan [2] by reference to an article of Harmandalıoğlu (Forum Dergisi issue number 167) also says that in Pötürge-Malatya, taking life used to be an indication of bravery and gallantry! Men used to stain their hands with blood merely for the sake of being considered as valiant! They used to compete with one another in proving their prowess, which was best measured in terms of the number of killings accomplished! Playwright Haldun Taner's unforgettable character Ali of Keşan eventually claims for a murder - while in jail as a mere suspectand is converted from the whipping boy of the ward onto a hero and later is engaged to a legendary bullyboy career. Similarly the hunchbacked town-crier (crier public / official announcer) in Yashar Kemal's previously mentioned novel, while innocent and nevertheless imprisoned as a murder suspect, boastfully claims himself as the murderer. But the (honest, decent) chief judge is not convinced during his trial.

Upon his release, the metallic-voiced deformed man, having once tasted the reputation of a murderer, will actually kill Kurtbogha (the real murderer of the blacksmith and the slanderer of himself) just underneath the huge plane tree in the presence of a dense crowd! Quick tempers are also responsible for trouble: "People, particularly the men, are quick to anger and quick to draw knives or guns. Even the boys carry knives, and hardly any adult villager goes unarmed. On one occasion a twelve-year-old lad was brought into us with a severe cut across his fingers. He had attempted, exactly like his elders, to intervene between two comrades who had drawn knives in anger, and had caught one knife by the blade. Over the years I had evidenced that the total number of acts of violence is considerable, and 
enquiries in other parts of Turkey led me to suppose that it is not in any way untypical" [3].

\section{Provincial criminality differs from the cities}

Chastity of females having an overwhelming significance many crimes of honor are committed on such grounds. İçli [4] lets us know that affairs involving women's honor and sexual jealousy constitute the first most important cause of murder cases in provincial Turkey (followed by feuding in the second order). According to Erdentuğ [5], in the village community the individual's honor and chastity means the honor and chastity of the entire community. In case of a rape committed against a woman, the whole village lynches the offender. Each villager considers it his duty to conform to the traditions and customs. Crimes originating from land disputes are just natural. Subsistence of the villager depends on land. People's affairs center on what is perceived by them as important, especially on economic terms. Certain writers explain the bride money from an economic outlook too. The woman works both in and outside house and contributes to the welfare. This is why bride money comes into question to balance the asset value represented here. My recent traveling comrade in the bus returning from the Aegean region, Roll-Bread (Sesamkringel) Baker Ahmet, told me about a violence incident in a village adjacent to his own village in Thrace: A coffee shop owner had a mentally deranged teenager son, who got beaten by two men. The coffee shop owner got into a rage. He took his revolver and shot the two men dead. Ahmet sympathized towards the killer and regretted his possible sort. "If it had been a single murder, then it wouldn't be so bad; now the penalty will be much too heavy" he reasoned. Besides one's own children, a fight involving a kin may also entail some others into trouble.

Stirling [3] confirms those judgments for the case of a Turkish village of the Province Kayseri, in Mid Anatolia: "The primary function of lineage groups, defense in quarrels, is no minor matter. Normally, it is regarded as the duty of a man to side with his agnates on all occasions and be prepared if necessary, to feud for them". Sexual crimes are sometimes committed in rural regions. When my mother was a village teacher, a teenager boy got raped, strangled and dumped into a flour bin in the wheat mill. Two accomplices were identified. One was a student in her class. Sometime later when I thumbed through my mother's grade note-book, I ran into that student. On the opinion space she had written "he is serving his prison sentence in the children's division of the district jail". One of my mother's colleagues, a green-eyed single female teacher was also harassed by a few lads while walking towards the village. Joking among themselves to the detriment of the young girl, they said things like "we should grab this green duck and throw her into the river." She was horrified. I vaguely remember that the lads were scolded and intimidated by the gendarmes upon her report. At that time, sexual harassment was not a properly defined offence as it is now. (My mother frequents her former colleague in Edirne. She once said the retired widow preserves the remnants of her former beauty. "The mosque may long be collapsed but the altar is still erect").

\section{Taking life}

In the village where my mother got appointed as a school teacher, another crime was committed before our arrival. A young man was shot dead by another young man, his peer and neighbor. The house of the killer was separated from the house of the victim by a third house, that of Cypriot Fatma Hanım (In her youth she somehow came to settle there) and she rented this house to my mother and moved into her second empty house and the killer's mother was Zekiye Woman. The rumor circulated that the weapon of crime, a revolver, was found inside Zekiye Woman's underpants during a frenzied search by other villagers, the watchman and the headman soon after the crime. The victim's nephew, Yusuf, was my peer and friend. He had a good voice and sang songs. He mourned his uncle and improvised épopées after him and propagated his legend. Yusuf's family was a well-to-do one. He went to Kepirtepe Teacher Training School as a day student and stayed at a paid Studentenheim at nights. In later years one day I visited him in his private boarding house. He showed me his dormitory room, his bunker, locker. He expressed his contentment about the life conditions and praised the food. Nevertheless, he kept saying "good, fine, but could it ever equal one's own house?". At the moment, I was about to take the entrance test for the state boarding Lycées and looking forward to better opportunities than my house could afford. (Haydarpaşa Lycée was my realistic dream). So, this comparison amazed me and upset me. A village boy as he was, he considered his home circumstances far superior.

\section{Bestiality, but not by choice}

It is no secret to state that village boys usually find an outlet for sexual satisfaction in the "person" of donkeys and maybe dogs. In her research at an Ankara village, Delaney [6] was curious about sexual matters but as a woman she had hard time obtaining information in that point. She reasoned that "sheep would seem to be the most likely candidates for sexual activity, since boys are often alone with them and sheep are docile." Informants of other authors then corrected her that "it was only possible with animals one does not eat". In a footnote Delaney says "I have since been told informally (and not by a villager) that sheep are not used for intercourse, but donkeys and dogs are." In fact, a shepherd would never do such a thing. Moreover, he would not let others to abuse his sheep in that sense either. Shepherds are respected personalities. They are friends of the nature and the stars. Many last names employ the word shepherd.

Prophet Moses is said to be a shepherd by trade. A famous French author Daudet praises a shepherd (berger) in one of his short stories. One day, Stephanette, the beautiful daughter of the owner of the herd (approximating the agha) brings his food, substituting herself for the regular food-bringing valet; but she gets marooned on the mountain top following heavy rainfall and the accumulated water pools. The shepherd 
starts up a dialogue with her, which is an honor for him. The inaccessible girl so often dreamt about is in his reach now. She finally falls asleep from fatigue and he covers her delicate body against the cold. Regarding her as the most precious lamb of the herd, he admiringly watches her beauty and listens to her easy rhythmical breathing for the rest of the night. He later thanks heavens for having protected him from a wrongful sinful act towards his platonic love [7]. In some regions like Konya villages, an expression in the sense "haven't you ever copulated with a donkey?" is directed towards a person who is clumsy and unskillful with his hands. I remember a scene from the comedy "Hastane mi Kestane mi?" (Is it the hospital or the chestnut? the two words rhyme in Turkish - from years back, where this donkey issue is insinuated though not openly expressed.

A nurse is checking the amnesia of a young man. He replies that he has no medical history of illness except for being kicked by a donkey once upon a time. The nurse goes on: "Why did the donkey kick you?" Then the counter reply follows: "Don't inquire into the reason why; that is a romantic matter." In classical legal medicine texts, sexual propensity for animals is defined as zoophilie or bestiality under the title of deviant behaviors; but here insistent and adult behavior is in question rather than a passing adolescent phase enabled by environmental opportunities and non-condemned if not provoked by cultural structure. An Islamic cleric said on a TV broadcast that the act is sinful and the doer should regret it and renounce it. It appears that abusing donkeys is not much of a horrifying thing in the peasant culture of this society. In some other societies, it may not be so.

\section{Chastity and the macho honor}

Flirting between young lads and girls is not explicitly done in eastern and southeastern and even in central Anatolian regions on the countryside. Elopement of a girl is almost always followed by serious trouble. In western villages boys may have furtive dealings with girls despite all preventive attempts by the village society. (Mutual jealousy then may or may not lead to trouble among competing suitors). While my brother was in summer holiday in high school days he got friendly with Ali, a village originated waiter. Ali had a girlfriend in his village. On some summer nights he secretly met her in a barn, putting my brother and another friend of his nearby as look-out men against the danger of getting busted by the family or village people. My brother confessed to those perilous cooperation only years later.

During my recent Aegean trip, when I took the train from İzmir to Aydın via Germencik, watching the countryside from the window, I saw an enlaced couple just near the railroad but protected from the opposite side by a hedge. The teen-age peasant girl was on top of the teen-age peasant boy kissing him passionately just at that moment! After the separation of my parents, the next summer my mother sent my elder brother to his Thracian village, to convey the idea of the hardship in caring for a child. He had a hard summer, waking up early and leading the cows to the meadow for grazing, barefoot. (My paternal aunts deliberately hid his shoes to make him resemble his peers). Nevertheless, he had his first platonic darling in the village, Hamiyet! After his return, the poor girl is said to have wept just behind the garden wall. Later on my elderly brother in school got play with another Hamiyet, a modern and also frivolous modern girl, the daughter of an official at the state-owned sugar plant. Perhaps her name, as a tribute to the first one, meant more to him than the girl herself. (This elderly brother of mine was an athlete at school; he died at a very young age).

\section{Village bouncer}

In some villages a tough man, the village bully may establish a domination by force over the other males and enjoy the resulting prerogatives. If the village is small in size his presence is felt more and is more irritating. My gym teacher cousin used to be a village teacher. (He is a bulky man and he would later place third in inter-universities weight-lifting championship). He once mentioned about the bouncer type in his village and I inferred his annoyance by the presence of the bouncer-type. When the bully is away, traveling or working elsewhere or serving another prison sentence, the village gains some respite. When my mother as a new bride visited my father's village she witnessed an incident in the grocery shop. A tall man with a stern face just walked in and practically took away a can of candy (halva). The grocer moved away from the counter as far as possible and kept silent. The man had a murder in his history and more than a decade of prison time. The title of "Killer" was a glorification for him rather than a stigma. Though in Turkish penal code the penalty for forced robbery is extremely (and disproportionately) heavy, he did not "give a damn" about it obviously.

A closer friend of mine than Yusuf, Hasan Hüseyin, one day revealed more about Yusuf's deceased uncle mentioned above. He had been a man seeking excuses to challenge others to fights: At wedding and circumcision ceremonies he used to spoil the calm atmosphere. Once he died, his former misdeeds were unmentioned and even forgotten. The saying says "the blind man dies and he becomes almond-eyed." His killer was a submissive person, probably one day he got fed up from the other's oppression and killed him. He did it in an ambush, not in one one-to-one fight. This point was stressed in Yusuf's legendry narrations of the killing and glorification of his dead uncle. (At the age of twenty-one, I encountered Hasan Hüseyin in a Thracian town. Ironically, he had kind of grown into the new bully of his village. He said "I have neither schooling nor a wife and children so I am fearless in front of probable trouble and don't hesitate to fight my way anywhere!"). In his superb novel A Painted House, John Grisham deals with the theme of bullies in a cotton farm in rural Alabama in early 1950's. The events are narrated from the eyes of a child, who at his small age also has his share in collecting cotton. The grandfather is a relatively poor cotton farmer. When the harvest time approaches he employs waged pickers. They are mountaineers or Mexicans. They set up their own cams at the barn or in the open. One of the 
mountaineers, Hank, is an all-muscle, defying type. One of the Mexicans, nicknamed "Cowboy" is a switch-blade master with a dark history behind. One day the wagers play baseball and then trouble emerges when Hank and Cowboy roughly compete with one another: [Cowboy had just pulled out a knife]. "He jerked it, and a very long switchblade popped free. Cowboy made a beckoning motion, as if to say, come on big boy. Hank was staring at the blade. The knife shocked everyone, and for a few seconds there was silence. Then my father, holding the bat, stepped between the two" [8].

(A few days before, downtown, a young man from the feared local Sisco family had been badly beaten by the mountaineer "Hercules" Hank and he had already gained a fighter's reputation in the vicinity of the farm). Then Cowboy disappears with Tally, Hank's sister. On an early morning hour before his departure he stabs Hank to death on a bridge. The narrator boy sees it all but keeps it secret. Hank's absence is not noticed because he had departed before his family. As the narrator boy's father guesses, "Cowboy and his new bride would simply blend into a vast city". (Later a rain soaks the cotton fields. The cotton gets too wet to pick and the ground too soft. Mud cakes on boots and sticks to picking sacks and the harvest are spoiled. Finally and the wagers break camp). "They had been camping out for six weeks in or front yard. Their old tents were sagging under the weight of the rain. Their sleeping mattresses were splattered with mud. We sat on the porch and watched them gather their junk and pack it all. I was suddenly frightened by their leaving. They would be home soon, and Hank wouldn't be there. If they had picked another farm, Tally wouldn't have met Cowboy. And Hank might still be alive, though given his lust for violence he was probably doomed to an early death" [8].

\section{Conclusion}

Violence on rural Turkey is different from the urban violence and occurs from time to time because of various causes peculiar to rural life style and human relations. The offenders are predominantly young people. Love of firearms and their illegal carrying seems to accelerate crime rates. While a committed crime means trouble for those parties directly involved, any crime is a lesson for the others and a source of annoyance spoiling the pleasure of life for a certain time interval.

\section{References}

1. Shaw GH $(1938,2003)$ "Türk Hapishane Sistemi ve Bunda Yapılan Reform" [Turkish Prison System and Related Reforms] in UĞURLU, Ö. A. In: Yabancı Gözüyle Cumhuriyet Türkiyesi (1923-1938) [Republican Turkey from the Eyes of the Foreign-Observer (1923-1938)], Örgün Printing House, Turkey, pp. 294-303.

2. Tezcan M (1981) Kan Dâvalarl: Sosyal Antropolojik Yaklașım [Vendettas: A Social Anthropological Approach] (2 ${ }^{\text {nd }}$ edn), Publications of Ankara University Faculty of Education, Turkey, p. 99.

3. Stirling P (1965) Turkish Village. Weidenfeld and Nicolson, USA.

4. İçli TG (1993) Türkiye'de Suçlular [Criminals in Turkey]. Publications of Atatürk Cultural Center, USA, p. 71.

5. Erdentuğ N (1977) Sosyal Âdet ve Görenekler [Social Customs and Conventions]. Publications of the Ministry of Culture, USA.

6. Carol Delaney (1991) The Seed and the Soil: Gender and Cosmology in Turkish Village Society. University of California Press, USA.

7. Daudet A (1869) Les étoiles (The Stars): a short story from the collection titled Lettres de mon moulin [Letters from my Windmill]. Librairie Hachette, Europe.

8. Grisham J (2001) A Painted House. Arrow Books, UK.

Your next submission with Juniper Publishers will reach you the below assets

- Quality Editorial service

- Swift Peer Review

- Reprints availability

- E-prints Service

- Manuscript Podcast for convenient understanding

- Global attainment for your research

- Manuscript accessibility in different formats

( Pdf, E-pub, Full Text, Audio)

- Unceasing customer service

Track the below URL for one-step submission https://juniperpublishers.com/online-submission.php 